\title{
Coping With Repression In Soviet Ukraine
}

\author{
Oxana Bayer, PhD \\ Ievgeniia Martyshenko
}

Oles Honchar Dnipropetrovsk national University, Ukraine

doi: 10.19044/esj.2016.v12n8p52 URL:http://dx.doi.org/10.19044/esj.2016.v12n8p52

\begin{abstract}
The psychology of the Soviet period in Ukraine still needs to be analyzed because living witnesses of those times are gradually passing away. In this mixed-methods study, a sample of 56 respondents aged 63-102 were administered a semi-structured interview created for discovering the ways and resources people used to overcome the oppression of the Soviet regime. A qualitative analysis of participants' testimonies through conceptualization revealed the following helping resources: social, financial, and informational support, faith, creative work, the example of family members, upbringing, humor, self-esteem, and morale, and taking responsibility. Though respondents mentioned all strategies, emotional reactions were notably missing from the strategies. Thus, participant responses were quantitatively analyzed for emotional content as well, allowing for detection of subjects' non-conscious attitudes towards the topic under discussion.
\end{abstract}

Keywords: Political dictatorship, coping, resources, Soviet repression

\section{Introduction}

The Soviet Union ceased to exist in 1991, but many lessons remain to be learned from it. The current problems in Ukraine-for example, lack of a national idea that would unite Ukrainians, low national dignity and civil awareness, and passive observation of destructive processes in the countrymake it even more important and urgent to examine how the years of the Soviet dictatorship influenced the way Ukrainians see the world and themselves (Yermolaev et al., 2011). The experience under the Sovety may, for many reasons, be regarded as a collective trauma for Ukrainians, which is certainly being transmitted to the successive generations of Ukrainians. In addition, Ukraine will neither be able to cope with it nor overcome it somehow if they do not discover its essence and acknowledge it.

In this article, our aim is to present the results of a pilot research project concerning the ways and resources local people used to cope 


\section{with social repression during the Soviet era in Ukraine, before and after the World War II in particular.}

I.

When living under a political dictatorship and social repressions, a person uses various survival or coping strategies. Under the reign of the Communist Party in the USSR, living circumstances were undoubtedly complicated, especially for those who did not support the official policy. Individual lives were regarded as having little value; what was important was the idea of the Sovety (the governing body that managed the country during the USSR period) and the implementation of particular tasks. Thus, people were perceived as the functions they served and nothing else.

During the seventy years of its existence, the USSR controlled all aspects of the functioning of the population. The citizens were deprived of personal space and were not the owners of their lives. Millions of people were arrested and killed as a result of senseless accusations or even without them. The grounds for arresting or starting other punitive actions included nonconformity, undesirable ethnic or religious affiliations, and a "wrong" social background (Applebaum, 2004; Hrynevych, 2012; Reva, 2013). There is vast evidence of repressive measures instituted by the Soviet regime in the territory of the Ukrainian Soviet Socialist Republic, especially in the countryside: individuals were denied property (food, tools), had limited access to resources, were deprived of the opportunity to obtain passports so that they could not leave the country, and were forced to work in a kolkhozy (a production unit of villagers meant for collective management of agriculture) under exhausting conditions and with a daily food allowance of very small portions. The population was divided into categories, two of them of particular note in terms of the Soviet regime. The first one was called the kurkuli, meaning "wealthy"; these people possessed private property. The second group was the serednyaky, meaning "middle peasants"; though there were other groups, these two were particularly targeted. Those in the first group and everyone having any connection with them were deported, and all their belongings were confiscated. Representatives of the second group were allowed to stay but lived under constant threat of oppression and pursuit. Any disagreement was strictly punished (Hrynevych, 2012).

Almost daily, the totalitarian regime made a person choose either to act according to his or her inner beliefs and take risks, or stay safe, yet feel scared and deceived. People could suffer from being unable to reconcile demonstrated behavior with their true values. In this way, the regime was destructive to their integrity and, as they acted contrary to their beliefs, to their self-respect. 
Although the consequences of the inhumane regime's impact on the self-consciousness of Ukrainians have been the subject of a number of studies, the questions about the personal traits or resources that may have helped individuals to cope with the atrocities of the Sovety are often not considered. We can clearly see parallels with foreign scholars' findings from other studies concerning the ability to withstand authoritarian or totalitarian state conditions (Baker \& Gippenreiter, 1995; Basoglou et al., 1994; Gailiene, 2005; Kazlauskas, 2008; Kukk \& Raun, 2007). Yet we do not know of similar research conducted on the Ukrainian population. Moreover, many of those who lived during that time and who could have participated in the Ukrainian "living history" have passed away, taking the testimonies of their experience with them.

Nowadays, there are quite a few studies of people's lives under the Soviet era repressions, including the labor camps (Allpebaum, 2004; Solzhenitsyn, 2007); eyewitness testimonies regarding those events have been published, (Riznykiv, 2013) and special web pages with relevant materials and interview collections have been created, (Dissident Movements in Ukraine, 2001; Official Web-Site of the Ukrainian Institute of National Memory, 2014; Memorial: Ukrainian Volunteer Cultural and Educational Charity Society Named After Vasyl Stus, 2006) etc. These works reflect different aspects of life under various forms of repression: they examine the GULAG camps; they analyze the Ukrainian community's transformation as a result of the Soviet regime's methods, ways of Soviet identity formation, and the means and methods of coping with current psychological and social problems. In our opinion, however, issues concerning people's resources and ways of coping with the oppression of the Soviet regime still remain unclarified.

Authors traditionally single out three types of reactions to life in a totalitarian state: resistance, compliance, and transformation in the world's perception. Anne Applebaum (2004) outlines the following ways that people survived in the GULAG camps:

- $\quad$ avoiding hard labor to spare physical strength

- laboring as a means of earning more money and getting more food

- soliciting social support (talking to like-minded people, forging friendships, caring for others, every relationship that meant spiritual matters)

- nurturing faith, prayers, and religious holiday celebrations as a kind of support among those who were religious people

- maintaining intellectual activities, such as theater-going, and singing

- strengthening dignity through caring for one's self, such as staying neat and clean (Applebaum, 2004).

In considering how people coped with their life circumstances, it is vital to understand what types of adversaries existed. Even a cursory 
overview of reactions to life in a totalitarian state and the ways people survived in labor camps easily demonstrates that the bigger the threat to survival, and the harsher the deprivations, the more people acted like organisms rather than personalities. We received the same impressions when talking to our respondents about what helped them cope. In this paper we do not focus specifically on how people lived through the Holodomor-a series of famines in the Ukrainian Soviet Socialist Republic that many believe to have been deliberately imposed by the Soviet officials (for such studies, see Pygih, 2007; Vasylenko, 2009 etc.). Yet, briefly speaking, this time in the history of Ukraine touches upon and forms part of the background for what is discussed in here; whatever the trauma, issues of morale, ethics, dignity, and the like often cannot coexist with animal terror, despair, and the feeling of helplessness brought on by one's inability to feed a starving, swollen child, for example. Likewise, we could not separate the participants' experience in living through the famine from the rest of their lives nor from their consciousness, as will be discussed later on.

The results of our theoretical analysis demonstrated that there were likely different strategies of coping with the oppression of the Soviet regime, and that a person would apply several strategies rather than a single one. We also assumed that there were some important resources for overcoming the hardships: for example, social, informational, and material support; faith; and having leisure time.

\section{Method}

In order to reveal the ways people coped with repression in Soviet Ukraine, we conducted unstructured interviews. As of 2015, those who had witnessed the Soviet oppression are at least 70 or 80 years old, and some of them are over 90. These people may have certain health, hearing, and eyesight problems; therefore, it would have been difficult for them to read questionnaires. They tire quickly, continuous intellectual effort exhausts them easily, and questionnaires often contain a lot of information to be processed. Moreover, we did not know of any questionnaires regarding the topic of our interest other than those concerning overcoming social repression in a historical context. Therefore, our research was exploratory, and from the array of information we obtained, we tried to single out the particular factors that relate to overcoming social repression.

We obtained and processed qualitative data-that is, data expressed in words and word units, not in figures. Conceptualization was chosen as the way to analyze the contents. It is commonly known that qualitative research is usually finished, not initiated, with hypotheses and theories. Therefore, it is often described as the best way to explore new data (Kelle, 2006; Potter \& Hepburn, 2005). 
This pilot research was conducted in Dnipropetrovsk and Dniprodzerzhynsk, Ukraine, in 2013 and from January through March 2014.

\section{Procedure}

We considered two criteria when inviting potential study participants: they were recruited based on their age (they had to be witnesses of the investigated period), and on their individual life stories from the Soviet times. The subjects were located through the Dnipropetrovsk Geriatric Home, the Museum of Dniprodzerzhynsk History, and referrals from Dnipropetrovsk Oles Honchar National University students. Among the study participants were those who were persecuted, blamed for nationalism, deprived of the right to work for political reasons, etc.

We contacted potential respondents via the telephone, and each participant was asked exactly the same question. We said that we represented a group of psychologists studying the ways people coped with oppression in Soviet Ukraine and the resources that helped them. We asked if the potential respondent would agree to take part in our research. A person would be asked a set of questions; all the interviews would be tape-recorded. If a person did not want to have the interview recorded, it would not be; all the testimonies would remain anonymous.

Though we received four refusals to participate, among the rest of our addressees, none of the respondents said they did not undergo any oppression from the representatives of the Soviet regime.

The interviews included the following topics:

- the person's basic life events and his or her life experience

- the person's childhood

- what helped him or her during the period of the research interest

(i.e., the period of oppression, when the subject may have been banned as a writer, deprived of jobs, etc.)

- who provided the subject with support if so

- what other resources helped the subject to survive during that period

Depending on the subject, interviews ranged from 24 to 186 minutes, the mean time for each interview being 55 minutes. All the interviews were recorded and later transcribed into scripts for a more detailed and easier analysis.

A personal appointment was scheduled with each respondent. Each of the participants signed an informed consent, and we discussed the issue of confidentiality with all of them. However, all of them stated they were prepared for not having their personal information coded in any case. Seven of the participants refused to have their testimonies recorded, explaining they did not feel like doing so, but they agreed to talk with the researcher, who took notes as they spoke. 
In addition to the qualitative analysis, we later decided to carry out a secondary, quantitative study focusing on the emotions revealed by the participants' responses. This decision was stimulated by the fact that the respondents either spoke fairly emotionlessly on topics that the interviewers found hard, or gave non-verbal reactions that contradicted to what they said. When we drew their attention to some inconsistencies in their accounts, they still tended to deny the fact that there was something more to what they had said openly. We found that this approach allowed us to derive a more substantial analysis of the phenomenon, as the two studies (qualitative and quantitative) complemented each other.

\section{Participants}

Out of the 60 people contacted, four refused to participate (two of these came from Dnipropetrovsk Geriatric Home and two more were students’ relatives).

The sample ultimately included 21 residents of Dnipropetrovsk Geriatric Home, 15 relatives of the Oles Honchar Dnipropetrovsk National University students, and 20 subjects located through the Museum of Dniprodzerzhynsk History.

These respondents included 32 men (57\%) and 24 women (43\%), their age ranging from 63 to 102, the mean age being 71.1. All the participants had lived in the territory of Ukraine during the period of our research interest.

\section{Qualitative Results}

Although our main objective initially was to ascertain, if possible, how people in Ukraine had coped with oppression during the Soviet years, we encountered a few minor, though somewhat surprising, problems in conducting the interviews. First, many of the participants were unwilling to discuss the harassment they had witnessed. Twenty-eight subjects (50\%, and interestingly, all of them either from the Geriatric Home or were the relatives of DNU students) stated they had never seen or heard anything about all those atrocities of the Sovety, which are now widely presented in the mass media. They reported no knowledge of any vragy naroda ("the enemies of the people”), no deportations, no forced withdrawal of food or belongings in their families or in the neighborhood, no informational blockade. We observed what appeared to be a determined, sometimes hostile, readiness to prove that the Sovety always did the right thing, that the course of the state policy, even if "something did happen," could be justified because of the situation in the country. In their minds-first, after the First World War and the civil war, and then after the Second World War - the strong hand" was needed to lead the country out of the mess. 
Despite denials, $100 \%$ of the interviews contained descriptions of the difficulties people faced because of the regime. Many participants reported restrictions on civil rights: thirty-two respondents (57.14\%) out of the sample stated that they were deprived of the right to study and even to leave the territory where they lived because they were residents of the countryside. Thirty-seven respondents (66.07\%) discussed the tough state labor norms and the very low salaries and food rations. Fourteen subjects (25\%) provided very vivid evidence of the famine (Holodomor) out of which they survived. Twenty-three respondents (41.07\%) recalled being forced to participate in propaganda meetings, wherein were "exposed" many dreadful anti-Sovety deeds arising from all imaginable enemies. Very often during such meetings, those who gathered found out that people whom they seemed to have known well and for a long time appeared to be vrediteli ("those making harm" to the country and its course of development). When we asked why nobody tried to defend his or her friends and neighbors from false accusations, the respondents stated that they saw what happened to those who opposed the authorities. They were either accused of being vrediteli, or they simply disappeared.

We must note, however, as observed earlier, that none of these testimonies prevented those $50 \%$ of the participants from stating that no harassment occurred. When we presented them with their contradictory ideas together (e.g., "You have just said that you could not leave the country because the authorities did not allow you to and you were not given the passport. Why at the same time do you say that life was good and that the state did no injustice?”), without any hesitation, people justified the regime. One person replied, "And what should they have done? This was a very hard time; the authorities had nothing to do." Another said, "You know, this is because of our people: if you do not teach them, they will never understand what is right." Someone else observed, "At all the times, life is difficult. Don't you have difficulties now, when you are young? So did we.” Thus, in speaking about the difficulties they faced, the participants seemed to have decided to prove to us that the life at that time was not as bad as it is shown now.

Another crucial point, without which the qualitative analysis of the interviews would be incomplete, is that all of the respondents wanted to talk about the war. Though we had explained the focus of the research to the participants, had instructed them on answering the interview questions, and were never the first to ask them about their World War II experience, in all the cases, the respondents wanted to discuss war events. They easily switched from the topic we proposed for discussion to the horrors of the war. In their stories, it was abundantly clear that in comparison to what they had gone through during the war, all the evils connected with the Sovety were 
much less devastating. The war itself is the type of event in their lives that could not be ignored or omitted when they were talking about their past.

Yet another observation is that the hunger and deprivation Ukrainians had experienced during the years of the so-called "great terror" (Hrynevych, 2012) seemed to have changed their mentality and demands, even their worldview. In the interviews, we heard the respondents seem to indicate that under post-war communism, they felt a sort of protection; they felt that they lived under the communism that had been promised to them by the authorities some time before. As one woman said about her life during the Leonid Brezhnev period, "I had an apartment, a job; I was not starving; I could buy new things from time to time- as not it communism?” She compared all these privileges to the life of her parents' family in a village, and was sincerely thankful to the authorities for "guiding" and "protecting" the people.

Once we had accommodated the participants' various approaches to the interviews, including their reluctance to ascribe blame to the Soviets and their eagerness to speak of the great traumatic event of World War II, we were able to glean from their comments a variety of coping strategies that they had used. In their testimonies, our respondents named the following resources that helped them cope with the oppression of the Soviet regime.

1. Youthfulness. The following statements were representative and common: "We were young, full of vitality; things seemed not as intolerable as they might seem now." "Because I was young, I was able to see things other than the way I see them now: I had one single dress to wear, we got scarce food to eat, we did hard manual labor, yet it was all right; we waited for communism to come; we believed life would get better and better, made friends with other young people, went to dances and sang songs togetherlife was good and interesting!”

2. A naïve world view. This phenomenon, according to Taylor and Stanton, (Taylor \& Stanton, 1985) is characteristic of estimation and coping processes. It seemed that sometimes the fact that people did not realize the terrible nature of the surrounding evil actually rescued them and helped them survive. One woman, for example, said that in the winter she had to put on boots and go to a distant village to study at a college in order to become a nurse. At that time, she did not have warm clothes or enough food to eat. Upon coming home, she would lie on the bed, facing the wall and saying nothing, because she was ashamed to acknowledge that she was hungry and that she had no strength to pull herself together and start doing something. This woman was an ardent defender of the Soviet regime; she had no intention of blaming her difficult life circumstances on the Soviet state. When she was five and her brother was two, her father had been taken away and put in prison, and he never came back. In speaking about this, she 
merely said that her "father was taken away"; she did not point out directly who did this and did not show any offense at this fact; rather, she spoke as if it were a normal event. This attitude may be an example of either (a) rationalization and even denial, or (b) a kind of cognitive simplicity, wherein events are not perceived as terrible and appalling and, therefore, do not traumatize people as much as they could have. Thus, we see that turning to psychological defense mechanisms may have become a way of coping with the atrocities of the totalitarian regime.

3. Social support. Nearly $95 \%$ of the subjects named support from others, such as family and friends, as vital in being able to cope with their trauma. Even though we often heard that certain topics could not be discussed, even in the bosom of the family, it kept them afloat. However, simply knowing that they had close people who cared about them and were ready to help and share their feelings kept them afloat. A female respondent said: "They [meaning the parents - O. B.] always waited for me at home. Mom was so afraid something would happen to me! She gave me the last piece of bread we had and always said 'I have had it already, don't ask and eat it!'” When something suspicious and unclear happened-for example, the father of this woman was "taken away"-the parents taught the children to stay away, not ask "silly questions," and pretend not to know in order to be safe. Interestingly, although this woman's parents taught her not to interfere, in her early adolescence she had probably already been influenced by the Soviet propaganda, as she speculated this way: "I thought it could not be that he [the classmate's father - O. B.] was taken for no reason. He must have done something wrong!”

Family support often appeared to be the most important. A female respondent spoke with gratitude about her grandfather's actions when her father was arrested as vrag naroda-that is, the enemy of the people: "Granddad was a teacher... And he protected me from others. Sometimes when children wanted to make friends with me, their parents forbade them to do this. There were different people. Some of them could say something like 'Do not talk to her; otherwise they [meaning authorities, militia, etc. - O. B.] will come to get us.' But other parents treated us in a different way. In a friendly way. 'This is a mistake, her parents are good,' they said."

4. Community of confederates. Twenty respondents (35.71\%) talked about links with the Dnipropetrovsk and Dniprodzerzhynsk intelligentsiya, meaning the circle of educated and politically and nationally conscious people. Those belonging to this circle could gather to exchange information on political life and news from other cities and abroad. When arrests occurred, representatives of the intelligentsiya organized a legal defense during the investigations and raised money for the convicted and their families. Communicating with confederates helped preserve one's beliefs 
and native language (as it was considerably infringed), and reinforced selfesteem through maintaining national and personal integrity.

5. Positive example of others. Those who were confident, calm, and sure of being right gave strength to weaker people, reassured them, and made them believe that things would get better. A male respondent spoke about one of the dissidents: "I did not know this man personally. But just knowing that he existed and lived somewhere close to me, in my town, inspired me. It meant that not everything was lost."

6. Personal mastery in any sphere. Knowing they had no power to change the situation around them, people might choose an aspect of life, such as work or a hobby, where they could strive for perfection, feel competent, and be the masters of their lives. Doing so was not easy because the regime tended to interfere with every sphere of people's lives. A person could have been deprived of the right to obtain the education he or she wanted or to pursue a career of interest simply because there was an alleged vrag naroda in the family; personal belongings could be withdrawn and never returned in the course of the struggle with vrediteli and their families. Even so, people could make an effort to stay free in their minds and, as a result, find some occupation in which they could develop themselves and from which they could derive satisfaction. People testified to many occupations that filled such a role for them: embroidery, physics, poetry, teaching, gardening, animals, reading, sewing, carpentering, drawing, traveling, and so on.

7. Information support. One of the male respondents said, "When I found myself among these people, they opened my eyes. Many of them had been imprisoned... They gave me lots of literature to read. And this supported me. It made me feel enthusiastic. I was sure everything would be all right and we would win."

8. The system of values. It is highly important that a substantial majority of respondents (34 out of 56 or $60.71 \%$ ) mentioned that the way they were brought up in their families was another inner resource that helped them become resilient so that they would not get lost in complicated situations. M. G., for instance, said that when he studied at the technical school, he was forced to switch to the Russian language. However, he was not encouraged to speak Russian when he was growing up, and he remained loyal to his native language: “According to the Soviet party policy, Russians were more intellectual, superior, and more educated. Here is one example of how Ukrainian-speaking Ukrainians turned into the Russian-speaking [Ukrainians]. I studied at the Technical School of Automation and Telemechanics. The teaching language was Russian. But the patriotic upbringing I received and my dignity did not let me switch to Russian; it was like self-betrayal.” 
Another respondent said, "I have been nationally conscious since my very childhood; nobody taught me this, and it was my family who taught this. Both my father and mother were nationally conscious.... Therefore, when I studied at the technical school, I searched for the support of Ukrainian people like me.” One more respondent says: "No one brought us up this way. We saw our parents' behavior. We heard them speak. We saw the way they treated each other. Nobody gave us lectures on this."

It is in the family where these basic living principles are formed. One of the respondents recalled the fact that when he reprinted a forbidden book by Ivan Dzyuba, Internationalism or Russification? [Internatsionalism ili rusyfikatsiya] and was blamed for it, the officials offered to let him write a denunciation of his friends. Yet he refused. "I remembered my granny's words that I must not denounce my friends or neighbors. So I did not mention a single name during the questioning."

9. Financial and other material support. Respondents reported being frequently supported by their relatives and friends, although sympathy and help sometimes came from total strangers. For instance, when K. I. turned out to have no job and no opportunity to obtain one because of KGB control, he was supported by a few friends and colleagues who were not frightened of talking to a man who had fallen into disgrace with the authorities: "I appeared to have no friends when the KGB's bomb exploded over my head. Only two Jews supported me. One of them had survived in the war [the Great Patriotic War (World War II) - O. B.]; another was under the threat of being dismissed from the university. And they raised money for me, raised it from Jews. First, I rejected it; I was ashamed. But I had two kids, and my wife had a low-paid job at a factory. They told me that it was not theirs; people gave it to them. And I accepted these payments for some time.”

10. Humor. Respondents often mentioned humor as a helping resource in harsh times. One of the respondents witnessed, "I was summoned to the KGB; they tried to force me to become their informant for some time, but I refused and cracked a joke about getting a job in the KGB. They laughed and one of them said that I could leave, yet 'remember-you do not prevent us from building communism.'” Another respondent recalled asking his friend in a letter to send him 10 copies of Oles Honchar's novel Sobor. After that, he was called to the Department of Internal Affairs and was told, "How could you do this? You called the Secretary of the Regional Committee a snoot!" In his response, the subject said: "And how could you do this? You broke the provision of the Constitution stipulating that the secrecy of correspondence is guaranteed by the law. So the authorities that are supposed to control the way the Constitution is observed are the first to break it!” 
11. Self-esteem and the need to preserve one's identity. These appeared to be another way of coping with the consequences of oppression in the Soviet period. One person observed, “One may call it conscientiousness or morale or some other name. I thought that flirting with the regime was humiliating for me. It infringed my dignity. I am a person of honor. I just wanted them to respect me as I am a human being; I have my dignity. Please, do not force me to agree with your position which I do not take; do not make me think the way you do because I won't. It is just inhuman. This is the way it went."

12. Taking responsibility. The very same respondent spoke of being responsible as one more important resource in coping. "A person needs to be himself or herself; a person needs to be responsible for himself or herself. And he or she wishes, of course, that somebody else was responsible for him or her. But in such a case, this person would have this 'somebody else' as a huge portion of his or her personality, including the feeling of freedom.”

We found it notable that for coping strategies, the subjects mentioned a wide variety except those relating to emotional factors (to borrow a term from Carver \& Connor-Smith, 2010). There was an example of problemoriented coping: "The more they interfered, the more stubborn I felt." There was also a case of avoidance strategy coupled with focusing on the problem: "We tried not to tell strangers what we were thinking of. And at the same time we socialized with like-minded people.” Another respondent expressed similar arguments, and ideas can be found in another respondent's testimony about the experience of oppression in a higher education organization: "First we expressed our thoughts freely. But then, when they started calling us to the Dean's office, we had to restrain our activities. It was the first year of the university, and we had to continue studying." Another subject said: "My father told me: 'Stand your ground: you don't know anything.' But nobody called me. They spoke only with people around."

A female respondent with cancer, aged 92 and a resident of the Geriatric Home, provided an example of accommodative coping-that is, cognitive adjustments (acceptance, cognitive restructuring, and scaling back on one's goals) that a person might make in response to constraints. This woman recalled the experience of her mother, who had to feed two children alone because her husband had been taken to prison for some invented political reason. She said: "OK, so they cut off more of our land? [This was where her family grew vegetables and wheat for the family. - O. B.] Let it be! Let them take it, we will do without it. I never ask anyone for anything, neither did my mother. They took away her only day off and made her work more? Well, we will survive! Everything will be fine, we will adapt to it. This is my philosophy; I always follow it.” 
Three respondents who experienced camp imprisonment for their political views gave testimonies that can be viewed as an example of meaning-focused coping. A male respondent said, "Probably, this was what our nation needed, what I personally needed, to get stronger and wiser, to realize the value of freedom and understand who was right and open and who was wrong and mean."

Proactive coping was also present in the testimonies. Respondents said that they had a plan for what to do if they were called to a KGB office, and they collected contacts of "necessary" people or organizations (meaning those who might help in case of emergency). Though this type of coping is very close to, and sometimes difficult to differentiate from, problem-focused coping, the literature differentiates between these two types of coping (Carver \& Connor-Smith, 2010; Taylor \& Stanton, 1985).

\section{Discussion}

To summarize the results, social, financial, and informational support, faith, creative work, family example, upbringing, humor, selfesteem, morale, and accepting responsibility all served as the resources for coping with the oppression during the Soviet time.

We heard the respondents mention all the strategies and resources of coping behavior known to the psychological sciences except emotional ones. One possible reason why our subjects did not mention emotional reactions as a coping strategy is that the memories were still very vivid, and the respondents did not want to bring them to life again. This idea is consistent with the results obtained by different authors who have researched the aftermath of PTSD (Gailiene, 2005). We also need to account for the fact that many years have passed, and thus, living witnesses of the Soviet regime oppressions are either those who used more efficient coping strategies, which might not include emotional reactions during such prolonged stress, or those who did not suffer as much as others. What should be emphasized is that there seemed to be no "clear" coping strategies but a certain mixture of what is described in the literature (Suls \& Fletcher, 2007). In further research, a comparative analysis could be done of how different regions of Ukraine coped with Soviet repression.

As mentioned previously, because the respondents revealed no emotion when speaking and because they did not name any emotional reactions as coping mechanisms, we decided to do a quantitative analysis of the emotional content of participants' interviews. We were also intrigued because their non-verbal reactions sometimes contradicted what they were saying. We believed that this combined approach to the research, given the missed emotional component, would allow us to obtain a more complete view of the topic. 


\section{Quantitative Results}

In order to obtain quantitative results from the testimonies, we used the transcripts from the tape-recorded interviews. The transcripts included everything that the respondents said (most of the time they spoke surzhyk-a mixture of Russian and Ukrainian that is typical of the residents of Eastern Ukraine). The length of the respondents' pauses was indicated as well as the total number of words spoken. The contents of all the scripts were analyzed and the texts were divided into parts. The first part consisted of setting up a contact with the respondents (later this part was omitted from the statistical word and pause analysis). The second part, which was connected directly to our research topic, we further called "the key topic." The third part included the respondents' references to other topics, and as we mentioned earlier, they mainly referred to their impressions of the Great Patriotic War in Ukraine, from 1941-1945. Comments about World War II constituted the third part. Finally, the fourth part included the participants' observations on the topics from their everyday lives, whether about the political situation in the country, or concerning family matters. The number of words in each part was calculated separately.

The next step was finding emotionally charged words. The words were divided into negatively valent (e.g., “afraid,” “terrified,” “in despair”) and positively valent (e.g., "happy," "cheerful," "hopeful”). It is important also to stress that when transcribing the interviews, we took into account the intonation of the speakers. Sometimes they did not mention emotions, yet the intonation left no doubt about the valence of the speaker's feelings. For example, when speaking about the authorities' cruelty and unexpected night visits with the purpose of arresting someone who was "guilty," taking them to a labor camp, or even shooting them pursuant to the decision of the troika (three random representatives of the authorities) without a trial, an 84-yearold female respondent said nothing about her feelings, but her speech altogether in all its aspects (intonation, facial expression, the sense of what was said) clearly indicated what she was feeling. "And what could we have done? No! Never! [Paused for 10 seconds - O. B.] People could not have done anything, why would they? They wanted to live, they had to stay away from this!” [Italicized words indicate emphasis in the respondent's speech O. B.].

Several hypotheses were verified in the research through $\mathrm{R}$ statistical language. We also derived several hypotheses through our original qualitative analysis of the data and then constructed graphs (Figures 1-5) with the help of the ggplot2 library. When we verified the hypotheses, all the cases of omitted data were excluded, using pairwise deletion.

Hypothesis 1. The average number of pauses per second on the key topic is larger than that pertaining to the rest of topics. 
We hypothesized that because of the traumatic nature of the events described, our respondents would pause more often and keep silent for a longer time. Such pauses may indicate thoroughness in searching for words, fighting internal resistance when talking to an interviewer, or lack of words because of strong emotions.

The hypothesis was verified with the help of the T-Wilcoxon criterion: $\mathrm{V}=225$, $\mathrm{p}$-value $=0.008516$. Figure 1 shows that the means of both the distributions that indicate the number of pauses for the key and other topics, and the measures of data dispersion are significantly different.

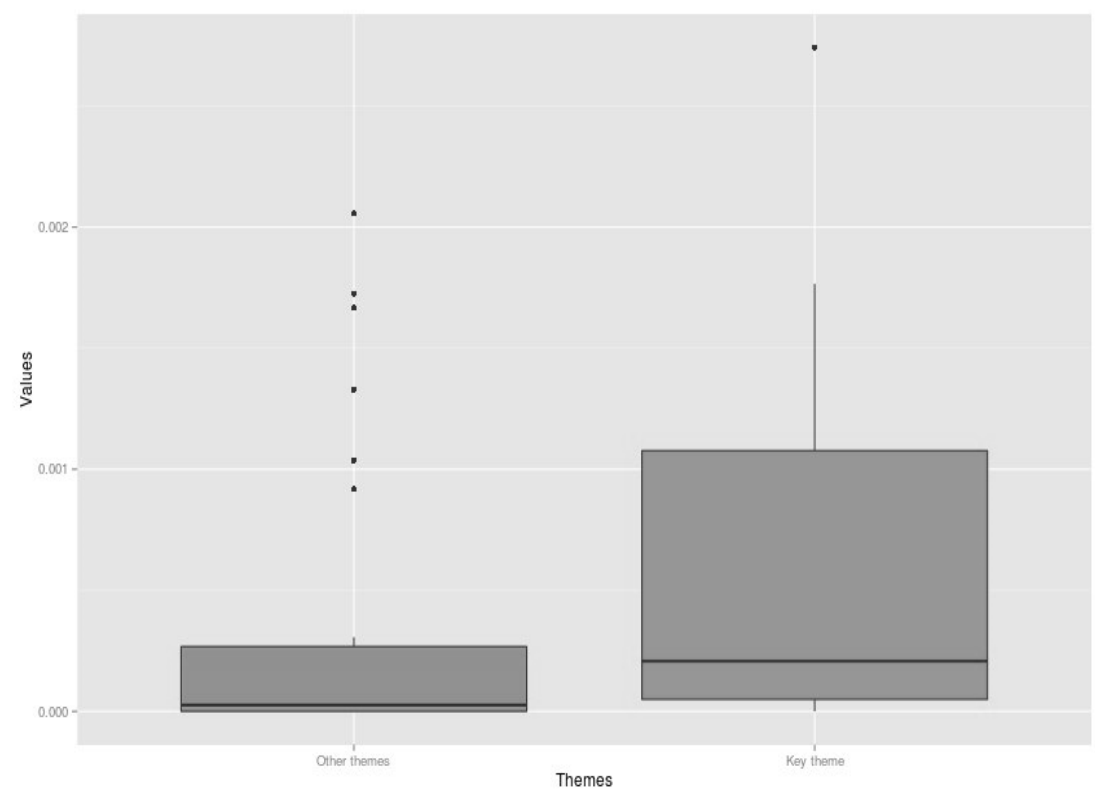

Figure 1. Boxplots of the distributions of the number of pauses in conversation about the key topic versus those on other topics

Hypothesis 2. The average duration of pauses for the key topic is longer than that for the rest of the topics.

When formulating this hypothesis, we explained this fact in the same way: when people are looking for words, taking pains to formulate their ideas, they need more time than usual. It may also be a sign either that the respondents are going deeply into their memories in order to produce an answer that is as clear and correct as possible, or that they feel resistant to discussing a complex and controversial topic. The hypothesis was verified with the help of the T-Wilcoxon criterion: $\mathrm{V}=173$, p-value $=0.294$. Thus, the difference between the distributions is not meaningful. When speaking about their life and difficulties caused by the regime in the Soviet time, our respondents did pause more frequently than they did when speaking about 
some other topics, but the average duration of the pauses was approximately the same.

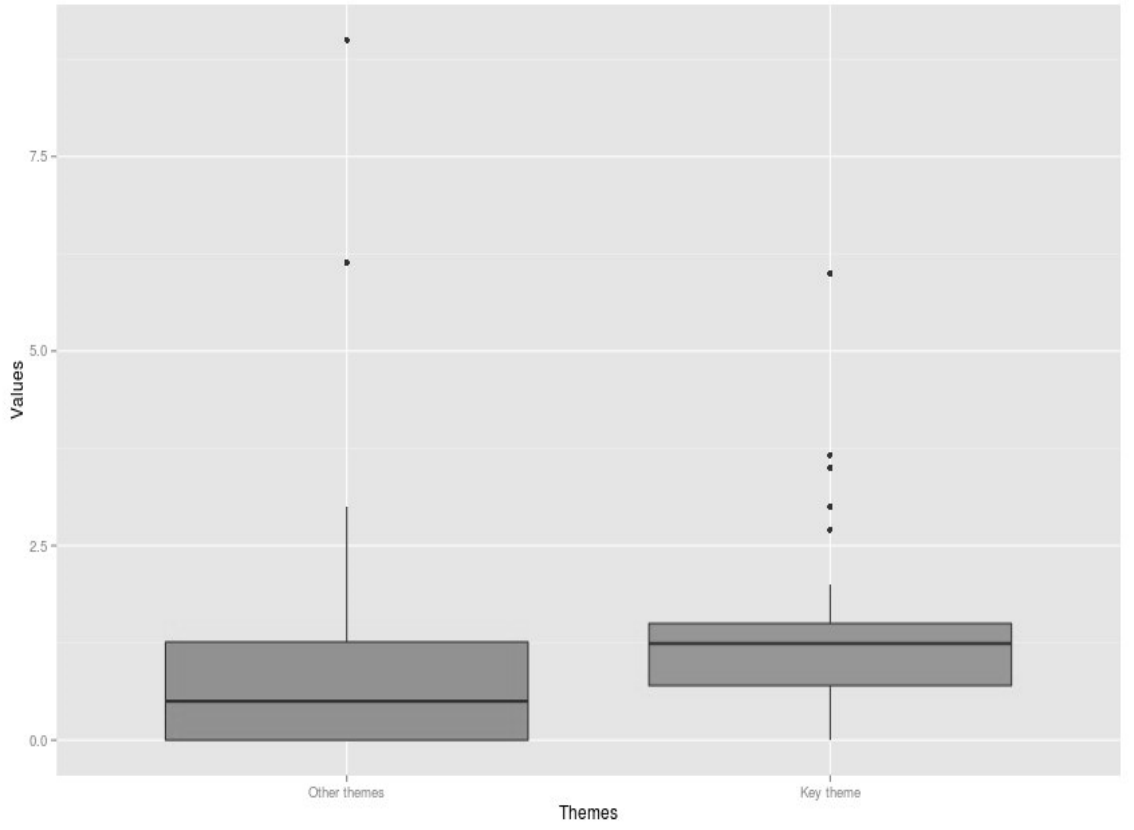

Figure 2. Boxplot of distributions of pause duration in conversation on the key topic and for other topics

Hypothesis 3. The number of words designating emotions (either positive or negative) relating to the key topic is different from that relating to other topics.

Earlier, we indicated that during the interviews, we constantly felt that our respondents were passionately trying to persuade us with their words and ideas, as they were not merely speaking about their lives in terms of our interest. This phenomenon was especially noticeable when dealing with the cases in which our respondents strongly insisted that there was no oppression and that the Sovety did only good to them.

Such behavior may have a couple of explanations. First, as the Soviet Union collapsed, official values changed, and those that had been supported during our respondents' youth were declared false (Krasnova \& Liders, 2003). The elderly people whose lives had been built on those values may, in their later years, feel confused or even deceived and may have difficulty with self-identification and building a non-controversial self-image. In other words, they may still be experiencing internal conflict. Therefore, when they were touching on a topic connected with the origin of their internal conflict, the respondents might react emotionally, and their attempt to convince us might be a signal that they are still trying to convince themselves. Second, 
such emotional persuasion, again, may be a sign of resistance to even stronger negative feelings rooted toward the evil that our participants faced at that time.

We must confess that we found it difficult to view this passion in speech as simply a sign of the desire to protect what the participants actually believed to be good in reality but unfairly blackened-because, as we mentioned before, they gave evidence of the regime's cruelty and inhumanity in every testimony, including those that defended the regime. We found this rather contradictory. Nonetheless, the testimonies were successive and logical, which supports this way of understanding the subjects' responses.

The hypothesis was verified with the help of the T-Wilcoxon criterion: $\mathrm{V}=318$, p-value $=1.132 \mathrm{e}-06$, demonstrating that the respondents' speech about the key topic was significantly more emotional than that about other topics. Figure 3 shows the data distributions: the number of words designating emotions in both the key topic and other topics.

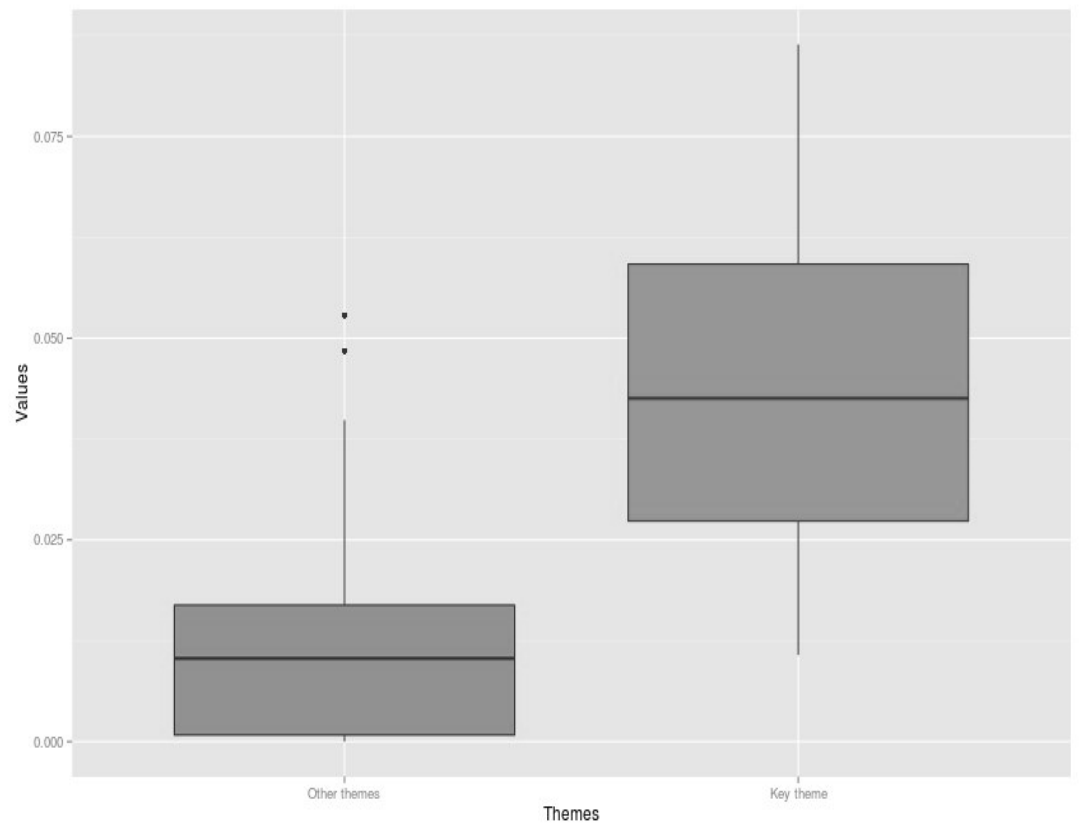

Figure 3. Boxplots of the distributions of the words designating in conversation on the key topic and for other topics

Hypothesis 4. The percentage of positively charged words for the key topic is larger than that for the other topics.

The next step was to determine whether the respondents tended to use more words with positive or negative connotations when speaking about the key topic. We speculated that if there were more positive words, it might be 
a sign of the psychological defenses a person uses against a background of powerful negative emotions or the acknowledgement of some painful ideas. We believed that if such was not the case, there would be no difference between the number of words with positive connotations relating to the key topic and the number used for other topics.

The hypothesis was verified with the help of the T-Wilcoxon criterion: $\mathrm{V}=322$, $\mathrm{p}$-value $=2.98 \mathrm{e}-07$ : when discussing the oppressions (whether perceived as real or invented, as some of them insisted) during the Soviet period, the respondents used more positive words than when speaking about other topics. Figure 4 illustrates the findings.

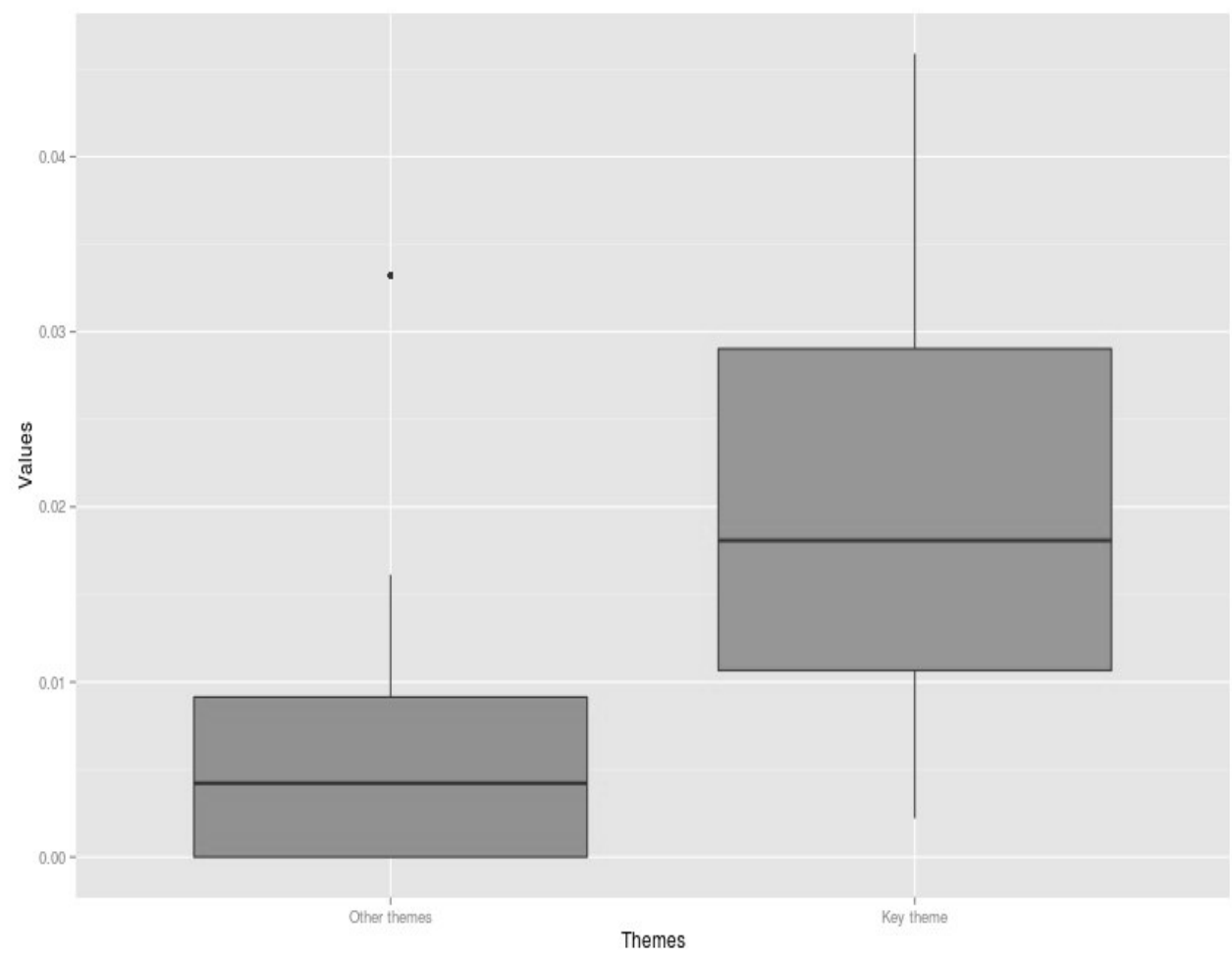

Figure 4. Boxplots of the "positive" emotional word distributions in conversation on the key topic versus those for other topics

Hypothesis 5. The percentage of negatively loaded words on the key topic is larger than that for other topics.

This prediction was again made on grounds that were hidden from our respondents. We hypothesized that when speaking about the harsh Soviet times and their lives, the subjects would involuntarily use more words with negative connotations (like “despair," "shame,” "fear," "loneliness,” etc.). 


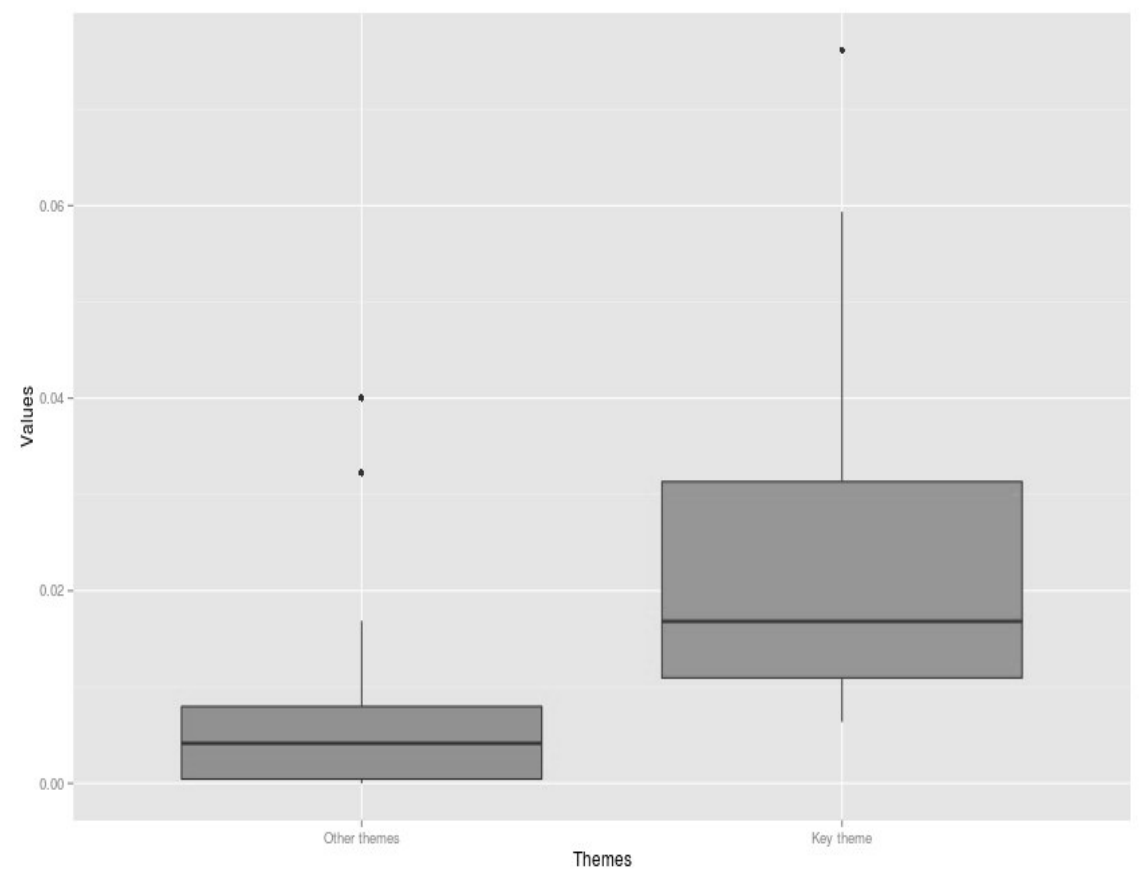

Figure 5. Boxplots of negative emotionally charged word distributions in conversation on the key topic and for that in other topics

The hypothesis was verified with the help of the T-Wilcoxon criterion: $\mathrm{V}=299$, $\mathrm{p}$-value $=6.366 \mathrm{e}-05$. Thus, when speaking about the Soviet times, the respondents not only used positively emotionally charged words more (see the verification of hypothesis 4), but also addressed the negative ones. As the participants had not been informed of our hypotheses and, hence, did not control what they said, we believe this is again evidence of the controversial nature of the phenomenon under study. Such saturation with emotionally loaded words, both negative and positive, in comparison with those used for the rest of the topics mentioned by our respondents demonstrates, in our opinion, their inner conflict regarding this matter, insufficient mental processing of the experience, and a lack of acceptance. Figure 5 shows the distribution of emotionally charged words with negative connotation in the key topic and other topics.

\section{Discussion}

The results of this research leave much space for further findings. The respondents clearly demonstrated that what happened to them in the Soviet times is controversial and that they have mixed feelings about it. Although there are those who find the Sovety undoubtedly evil, there are also those who, despite giving testimonies of multiple limitations in rights, 
readily justify those acts of the state. The latter find such actions excusable because of the complicated economic and social conditions within the Soviet Union or even the evil nature of some ignorant representatives of the authorities who would abuse power and demonstrate cruelty and indiscretion.

\section{Conclusion}

In the future, we might continue our research by creating a set of questions concerning specific resources and ways of coping with adverse life circumstances. The questions can be composed based on the autobiographies of immigrants from the Soviet Union and Soviet Ukraine in particular (Diasporiana, 2015), similar research in other countries, pursuit and oppression resistance theoretical analysis, as well as interviews analysis, especially the interviews considered in this article.

We again would like to emphasize the importance of intensifying such research, because fewer and fewer witnesses of the Soviet epoch can give live testimonies of their experience. They do want to share it and-as elderly people often do-teach their lessons to new generations.

The authors are grateful to Kirill Zakharov (Promedia Consulting, Dnipropetrovsk) for his guidance and assistance in doing the quantitative analysis.

We would like to thank Editage (www.editage.com) for English language editing.

\section{References:}

Applebaum, A. (2004). Gulag: a History. New York, NY: Anchor.

Baker, K. \& Gippenreiter, J. B. (1995). “The Impact of Stalin’s Repressions at the End of the 1930s on the Lives of Families in Three Generations" [Vliyanie stalinskykh repressiy kontsa 1930-h godov na zhyzn semei v tryokh pokoleniyah], Issues of Psychology 2 (pp. 66-84).

Basoglou, M., Paker, M., Paker, O., Ozmen, E., Marks, I., Incesu, C., Sahin, D., \& Sarimurhat, N. (1994). "Psychological Effects of Torture: A Comparison of Tortured with Nontortured Political Activists in Turkey," American Journal of Psychiatry 151, no. 1 (pp. 76-81).

"Dissident Movement in Ukraine: Virtual Museum, 2001," last modified February 27, 2015, accessed May 05, 2015, http://museum.khpg.org/eng.

Gailiene, D. (2005). The Psychology of Extreme Traumatisation: The Aftermath of Political Repression. Vilnius: Vaga.

Hrynevych, V. (2012). Unbridled Dissonance: The Second World War and Socio-Political Identities in Ukraine, 1939-June 1941. Kyiv Dnipropetrovs'k: Lira. 
Kazlauskas, E. (2008) "Long-term Posttraumatic Effects of Communism Regime Repression in Central and Eastern Europe,” XXIX International Congress of Psychology. Berlin, Germany (pp. 378-379).

Kucher, M. I. (1996). Dubravlag [in Ukrainian]. Dnipropetrovsk: Dnipro.

Kukk, K. \& Raun, T. (eds.) (2007). Soviet Deportations in Estonia: Impact and Legacy. Tartu University Press.

"Memorial: Ukrainian Volunteer Cultural and Educational Charity Society Named After Vasyl Stus, 2006,” last modified April 23, 2015, accessed May 05, 2015, http://memorial.kiev.ua/.

"Official Web-Site of the Ukrainian Institute of National Memory, 2014," last modified April 30, 2015, accessed May 05, 2015, http://www.memory.gov.ua/.

Osypchuk, R. (2010). Memoirs [Spogady]. Dnipropetrovsk: Self-published.

Prilleltensky, I. \& Gonick, L. (1996). "Polities Change, Oppression Remains: On the Psychology and Politics of Oppression,” Political Psychology 17, no. 1 (pp. 127-148).

Pygih, R. (ed.) (2007). The Holodomor of 1932-1933 in Ukraine: Documents and Materials [Holodomor 1932-1933 rokiv v Ukraïni: dokumenty i materialy]. Kyiv: Kyiv-Mohyla Academy.

Reva, I. (2013). Beyond Oneself: Socio-Psychological and Cultural Aftermath of Holodomor and Stalin Repressions [Po toi bik sebe: sotsialnopsyhologichni ta kulturni naslidky Holodomoru i Stalinskyh represiy]. Dnipropetrovsk: Svidler.

Riznykiv, O. (ed.). (2003). Zone: Literary Collection [Zona: literaturnyi zbirnyk]. Odessa: Ukrainian Society of Political Prisoners.

Solzhenitsyn, A. (2007). The Gulag Archipelago Abridged: An Experiment in Literary Investigation. New York, NY: Harper.

Vasylenko, V. (2009). The Holodomor of 1932-1933 in Ukraine as a genocide crime: legal aspect [Holodomor 1932-1933 rokiv v Ukraïni yak zlochin henotsydu: pravova otsinka]. Kyiv: Olena Teliga.

Yermolayev, A., Levtsun, A., \& Denisenko, S. (2011). The Ukrainian Character: Typical Social and Psychological Characteristics of the Population in Ukraine) [Ukrainskiy kharakter (kharakterniye sotsialnopsihologicheskiye osobennosti naseleniya Ukrainy)]. Kiev: Sofiya. 